\title{
Management Implications of Aquifer Fractures on Ecosystem and Habitat Suitability for Panthers in Southern Florida
}

\author{
Wenjing Xu1,2, Sergio Bernardes ${ }^{1}$, Sydney T. Bacchus ${ }^{1}$, Marguerite Madden ${ }^{*}$ \\ ${ }^{1}$ Center for Geospatial Research (CGR), Department of Geography, University of Georgia, Athens, Georgia, USA \\ ${ }^{2}$ Present Address: Department of Environmental Science, Policy, and Management, University of California, Berkeley, California, \\ USA \\ Email: *mmadden@uga.edu
}

How to cite this paper: $\mathrm{Xu}, \mathrm{W}$., Bernardes, S., Bacchus, S.T. and Madden, M. (2018) Management Implications of Aquifer Fractures on Ecosystem and Habitat Suitability for Panthers in Southern Florida. Journal of Geoscience and Environment Protection, 6, 184-208.

https://doi.org/10.4236/gep.2018.62012

Received: December 15, 2017

Accepted: February 25, 2018

Published: February 28, 2018

Copyright (ㅇ 2018 by authors and Scientific Research Publishing Inc. This work is licensed under the Creative Commons Attribution International License (CC BY 4.0).

http://creativecommons.org/licenses/by/4.0/

\begin{abstract}
Our case study analyzed the proximity of previously mapped fractures in the aquifer matrix to 93 Florida panther (Puma concolor coryi) dens mapped from 2007-2016 in south Florida. Dens occurred in five counties (Collier $=77$, Dade $=1$, Hendry $=9$, Lee $=5$, and Monroe $=1$ ) and three sub-basins of the Greater Everglades Basin (Big Cypress Swamp $=83$, Caloosahatchee $=3$, and Everglades $=7$ ). Fractured aquifers occur worldwide, but are not the focus of habitat suitability studies, despite evidence that fractures influence plant species composition and density. Habitat alterations can occur many kilometers from the surface footprint of groundwater alterations in the regional Floridan aquifer system via preferential flow through fractures. Increased natural discharge from and recharge to the aquifer occur at fracture intersections. Greater induced recharge and habitat changes also may occur at fracture intersections. All dens were within $5 \mathrm{~km}$ of a previously mapped fracture; $36 \%$ and $74 \%$ were within $1 \mathrm{~km}$ and $2 \mathrm{~km}$, respectively, of those fractures; and $47 \%$, $74 \%$, and $90 \%$ of dens were within $2 \mathrm{~km}, 3.25 \mathrm{~km}$ and $5 \mathrm{~km}$, respectively, from the nearest fracture intersection. Results suggest fractures influence the suitability and/or availability of habitat for panther dens, selection of den sites, and availability as well as abundance of high quality prey items essential for the nutritional demands of successfully rearing panther kittens in the wild. We recommend more detailed investigations of: a) vegetation characteristics near dens, b) groundwater alterations and cumulative impacts of those alterations associated with fractures in panther habitat (e.g., altered plant species composition and density), and c) influence of aquifer fractures in all habitats underlain by fractures.
\end{abstract}




\section{Keywords}

Ecosystem Management; Forest, Land, and Water Resources; Geographic Information System (GIS); Land Use; Remote Sensing; Sustainability

\section{Introduction}

Fractures (including faults and joints) are characteristic in the rock matrix of karst aquifer systems (with associated sinkholes), occur in other types of aquifer systems, and are associated with subsidence and alterations of natural hydroperiods in response to groundwater withdrawals and other types of mining worldwide [1]-[6]. Despite these widespread aquifer responses, studies of habitat and ecosystem management, requirements for conservation and preservation, land use, water resources, and sustainability of natural resources generally do not consider influences of aquifer fractures or altered hydroperiods.

We conducted a case study of the Florida panther (Puma concolor coryi, previously Felis concolor coryi), a subspecies of North American pumas (aka mountain lions, cougars (Puma concolor)), which previously inhabited all of Florida and much of the southeastern United States (US). We reviewed literature of habitat studies for the Florida panther and evaluated the proximity of panther dens to previously mapped fractures in the matrix of the regional Floridan aquifer system underlying the remaining and original panther habitat throughout the southeastern US. Currently, Florida panthers are restricted to less than $5 \%$ of the historic range, as a single breeding population in south Florida [7] [8]. On March 11, 1967, the Florida panther was listed as an endangered species in the 32 Federal Register 4001 and on May 26, 2006, the Florida panther was recognized as one of the rarest large mammals in the US, in the 71 Federal Register 30156-01.

In 1987, the population of Florida panthers was estimated at 20 to 50 individuals [9], suggesting a lack of variation in the population [10]. According to those sources, no published accounts of maternal behavior for Florida panthers were available at that time. This lead to the monitoring of behavior patterns associated with rearing of kittens, using two radio-collared adult female Florida panthers. Data collection occurred during the first 6 months after parturition from January 1985 through December 1987 by Maehr et al. [11]. That study was conducted in Collier County, Florida, which is dominated by large tracts of public lands (e.g., Big Cypress National Preserve and Fakahatchee Strand State Preserve) and similarly large tracts of privately owned lands. Despite the small sample size and limited period of that study, they observed that home-range size was reduced immediately after parturition, followed immediately by an increase in area used by one female panther (identified as " 09 ") and a decrease in area used by the other female panther (identified as " 11 "). 
Prey abundance was considered as an explanation for some of the behavioral differences observed between those two female panthers. Maehr et al. [11] noted that a "lower nutritional plane may have been the most important factor influencing the number of surviving kittens and larger home range" for the former panther, with only one surviving kitten, compared to the latter panther in that study, which revealed signs of as many as three kittens surviving for at least 2 years. They also concluded that contrasting home range sizes and movements after the denning period also may be due to habitat differences, noting that the area occupied by female 09 was characterized by poorer soil conditions.

According to Denny [12], poorer soil conditions may contribute to lower densities of white-tailed deer (Odocoileus virginianus), but subsequent research showed that those deer preferentially use areas where upland forest is adjacent to swamps [13]. The habitat preferences of these deer are important, because they are panther prey with a higher caloric return per unit effort than smaller mammals (e.g., raccoons (Procyon lotor), nine-banded armadillos (Dasypus novemcinctus), and other small mammals) utilized by panthers as prey [14]. Mountain lion kittens generally remain in their natal dens for the initial eight weeks after birth, restricting the movements of their mothers to areas close to the den. Although older kittens can follow their mothers, the limited mobility of the kittens may restrict both speed and distance of movement of the mothers [15] [16]. Similar behaviors may be occurring with Florida panthers.

Maehr et al. [11] described the natural vegetation in their study area as including "pine/palmetto flatwoods, mesic hammocks, freshwater marshes, wet prairies, mixed swamps, cypress swamps and cabbage palm forests", based on Davis [17]. The vegetation at the den sites for both of the panthers in the Maehr et al. [11] study was described as native vegetation that was so dense it was nearly impenetrable to the investigators. That dense vegetation was similar to the extremely dense vegetation surrounding ocelot (Leopardus pardalis, referenced in that study as Felis pardalis) dens in Peru described by Emmons [18]. More specifically, the den characteristics for panther 09 was described as "located at the edge of a live oak (Quercus virginiana) hammock in a dense thicket of grape vines, bracken fern (Pteridium aquilinum), wax myrtle (Myrica cerifera) and swamp dogwood (Cornus foemina)." The den characteristics for panther 11 were described as a slight depression in a dense palmetto (Serenoa repens) thicket $1-2 \mathrm{~m}$ tall. Subsequent studies evaluating greater numbers of panthers and den sites focused on large-scale habitat types (e.g., cover types), rather than specific plant species and growth habits of those species.

Benson et al. [19] conducted a larger-scale evaluation of the role of habitat types for selection of natal den sites by the federally endangered Florida panthers using three aerial telemetry flights per week from 2000 to 2006 to locate all radio-collared panthers. They performed a Euclidean distance analysis on 51 natal den sites of 30 female panthers in south Florida to determine which habitat types were selected and avoided. In that study, three habitat types (i.e., freshwater 
marsh and wet prairie, sawgrass marsh, and cattail marsh) from the original land cover were combined into one habitat type (i.e., freshwater marsh-wet prairie) as the modified land cover for the study. Conclusions were that panther dens were closer to upland hardwoods, pinelands, and mixed wet forests and farther from freshwater marsh-wet prairie habitat. They also recognized that the availability and quality of natal denning sites can influence fitness because parturition and parental care occur at natal sites. The panther dens in that study were located on portions of the Florida Panther National Wildlife Refuge, Everglades National Park, Big Cypress National Preserve, Okaloacoochee Slough Wildlife Management Area and State Forest, Fakahatchee Strand Preserve State Park, Picayune Strand State Forest, Big Cypress Seminole Indian Reservation, and private lands bordering those areas. Benson et al. [19] suggested that hydrology and the resulting understory conditions in upland habitat types may be a factor in why some female panthers selected pinelands and upland hardwoods as den sites.

A year after the study by Benson et al. [19] was published, suggesting hydrology may be a factor influencing habitat and selection of den sites by female panthers, Blanco [20] released a master's thesis that used Euclidean distance analysis to determine stages of post-fire habitat preferred and avoided for panther dens. Blanco's [20] study evaluated 43 dens of radio-collared panthers within the Florida Panther National Wildlife Refuge. Results suggested that "panther dens were closer to habitat that had burned $\leq 4$ years prior to denning", but "no preference or avoidance was shown for habitat burned $\geq 4$ years prior to denning". An expansion of that analysis, using additional dens, currently is being conducted for publication (personal communication, Dave Onorato 07/31/17)

Florida panthers are nocturnal and crepuscular, with peak activity around sunset and sunrise. They generally rest during other times in day beds [11] [21]. Therefore, previous studies tracking movements of Florida panthers only during the day to determine habitat utilization by Florida panthers have been criticized for failing to collect movement data from sunset, throughout the night, to sunrise. In an effort to correct this deficiency, Onorato et al. [22] used 20 independent Florida panthers with GPS collars to evaluate habitat selection using a Euclidean distance analysis and location data collected throughout the diel period. In addition to corroborating aspects of earlier analyses by demonstrating the selection of forested habitats, that study also confirmed the novel result of Florida panther's selection of open habitats (i.e., marsh-shrub-swamps, prairie grasslands) and that habitat selection varied by time of day, but not by sex or season. The panthers in that study were located closer to wetland forests in the daytime, with increased use of prairie grasslands at night. Patch-size analysis on selection of forest habitat showed those panthers utilized forest patches of all sizes (e.g., $\leq 1,>5-10,>1000 \mathrm{ha})$. The results of that study emphasized the importance of: a) collecting panther location data throughout the diel period to assess habitat 
selection and b) including a mosaic of habitats in south Florida to protect the panthers and other sensitive flora and fauna [22].

Frakes et al. [7] used radio-telemetry data from 2004 through 2013 for 35 adult male and 52 adult female panthers to create a 10 -fold cross-validation model to predict the presence or absence of panthers in the study area, which encompassed 16,678 $\mathrm{km}^{2}$. This presence-absence model assumed absences for grid cells lacking a telemetry location, although undetected panthers could have occurred in those locations. The landscape variables for that study were vegetation cover types and land uses obtained from the Florida Land Use and Cover Classification System (FLUCCS) Geographic Information System (GIS) database, combined to create 10 major land cover categories. Sensitivity analysis was conducted by determining the model's response to a single predictor while holding the other predictors constant.

Although that study did not focus on den sites, those model results were significant in revealing that hydrology was one of the most important factors determining the presence and absence of adult panthers. The amount of forests and forest edge, and human population density also were important factors. Presumably this was the first model to identify the importance of water depth and forest edge in panther habitat use. More specifically, that model indicated the probability of adult-panther presence was greatest when average water levels were just below the surface, but declined rapidly as water depths increased or decreased. Water depth for the model was determined by subtracting ground-surface elevation from a corresponding stage elevation (water level), although negative and positive depths of water in the model only suggested that most, but not all of a cell was dry (upland) and wet (wetland), respectively. That model indicated only $5579 \mathrm{~km}^{2}$ of suitable adult panther (breeding) habitat remains in south Florida. Frakes et al. [7] also stated that $25 \%$ of that suitable habitat was in non-protected private ownership.

Van de Kerk et al. [23] evaluated the movement of 13 Florida panthers using hourly global positioning system (GPS) tracking data and hidden semi-Markov models (HSMM). The modeled data in that study determined that males and females, and females with and without kittens exhibited distinctly different movement patterns, but did not specify if those different movements were within the same habitat types, as suggested by Frakes et al. [7], or in different habitat types. Only one female panther carrying a GPS collar gave birth during the van de Kerk et al. [23] study. That study also compared the movements of those panthers during wet and dry seasons, defined by Frakes et al. [7] as June through October and November through May, respectively.

None of those studies evaluated the association of panther dens or panther movements with previously mapped fractures or the influence of fractures on the quality of habitat used by panthers within the approximate breeding range and area of the remaining panther population in south Florida. Remote sensing has been used to detect linear features (also known as lineaments) since at least 
the 1950s, including vegetation aligned in linear patterns indicative of fractures, as described in Lines et al. [24]. That study summarized the influence of fractures, other karst conduits and sinkholes on preferential groundwater flow in Florida and how that preferential flow affects other types of subsidence. Lines et al. [24] also provided previously published definitions of key terms and examples of cumulative impacts related to this preferential flow. Examples included all eight types of cumulative effects listed in the 1997 report by the US Council on Environmental Quality titled, "Considering Cumulative Effects Under the National Environmental Policy Act." Bacchus [25] [26] and Lines et al. [24] discussed specific examples of catastrophic, destructive wildfires and land subsidence resulting from groundwater alterations in Florida's highly fractured, semiconfined carbonate aquifer system and how those wildfires and subsidence can occur considerable distances beyond the surface footprint of the pumping sites.

Bacchus [27] and Bacchus et al. [28] identified additional, comparable off-site habitat impacts from all types of mining and for phosphate mining, respectively, which included both groundwater mining (unsustainable pumping from wells) and physical mining of the aquifer system matrix in Florida. Bacchus et al. [29] presented evidence of the distance from the source that adverse impacts to habitat can occur as the result of preferential flow through fractures. The results of that study suggested that preferential flow occurred through the areas of the panther habitat studies described above. Additional evidence of preferential flow through fractures in the Floridan aquifer system also was provided by the rapid loss of water injected into aquifer storage and recovery (ASR) wells, intended for storage and later use [30] [31]. Bacchus et al. [30] also discussed the role of groundwater mining, extending through fractures as preferential flow, in destroying habit throughout south Georgia and north Florida.

These adverse impacts to habitat occur because the Floridan aquifer system is a semiconfined, karst aquifer system linked to the overlying surficial aquifers, with drawdowns that are not accurately predicted by groundwater flow models [32]. The studies referenced above, describing numerous types of adverse impacts to habitat associated with preferential flow through fractures in the Floridan aquifer system, provided scientific support for our investigation. We evaluated the proximity of panther dens to fractures and fracture intersections and the potential impact of those features of preferential flow on the integrity of habitat essential for the recovery and long-term survival of the Florida panther.

\section{Materials and Methods}

\subsection{Review and Data Analysis}

Our case study is a combined approach of a review and interdisciplinary research paper, including existing field data for locations of panther dens and telemetry of female panthers with kittens. Land-use we considered included locations of groundwater withdrawal wells. Remote sensing was used to evaluate association of panther dens in south Florida with fractures previously mapped us- 
ing aerial photography, satellite imagery and ground truthing. The literature selected for review in our case study included published literature and a master thesis of research specifically designed to evaluate Florida panther habitat, with emphasis on habitat for den selection and relevant literature on surface influences of fractured aquifer systems. Geospatial analysis was conducted in ArcGIS Version 10.2, as described in Bacchus et al. [30], to assess locations of fracture lineaments, withdrawal wells, and panther dens. Political boundaries from the US Census Bureau, including county limits, were used as reference during georeferencing. Spatial frequency analysis of previously mapped linear features indicative of fractures also was conducted as described in Bacchus et al. [30]. The "Either" category of fractures in histogram figures considered the closest fracture to each den, when both US Army Corps of Engineers (ACOE) and Florida Department of Transportation (FDOT) data were used during calculations. The following steps were used to compute the "Either" category: 1) sort the list of distances; 2) select rows from the sorted list that match a histogram bin; 3) from those selected rows, identify which data source (ACOE or FDOT) contains the closest fracture to a den; 4) count the number of rows for the identified data source within the distance bin that belong to the same data source as the closest feature (this is the closest data source for that particular bin); and 5) use the resulting total count from step 4 as the "Either" value. Values on the $\mathrm{X}$ axis represent the upper limit of the histogram bin. For example, $0.5 \mathrm{~km}$ represents all values greater than $0.25 \mathrm{~km}$ and less than or equal to $0.5 \mathrm{~km}$.

\subsection{Shapefiles and Other Data Obtained from Agencies}

Locations of 93 panther dens identified in 2007-2016 and telemetry data evaluated in our case study were obtained from the Florida Panther Project. The shapefile for the boundaries of the primary panther habitat zone was downloaded from the Florida Fish and Wildlife Conservation Commission (http://geodata.myfwc.com/datasets/b637ced9e6844b4dbfcbcf71ab6b3a75_35). The locations of the groundwater withdrawal wells permitted by the South Florida Water Management District (SFWMD) and the Southwest Florida Water Management District (SWFWMD) were created from location information included in the databases provided by those agencies, respectively. The acquisition methods for the FDOT [33] lineaments in Florida were described in Bacchus et al. [29] and Lines et al. [24]. This is the most extensive fracture network mapped in Florida and covers the entire state. Shapefiles not available from the ACOE for the lineaments representing extensive networks of fractures, shown as the "Lineament map of south Florida" (Figures 3-7 in ACOE [34], originally from ACOE [35]), were created by converting the analog file to a digital file as described in Bacchus et al. [30]. The basemap source for Figure 1, Figure 2, and Figure 5 was provided as "Esri, Digital Globe, GeoEye, i-cubed, Earthstar, Geographics, CNES/Airbus DS, USDA, USGS, AEX, Getmapping, Aerogrid, IGN, IGP, swisstopo, and the GIS User Community." 


\section{Results}

\subsection{Location of Panther Dens Identified in 2007-2016 by the Florida Panther Project}

All 93 of the panther dens identified by the Florida Panther Project in 2007-2016 are located in five counties (A-E) in south Florida (Figure 1(a)). All five of these counties are within the south Florida sub-region of the Floridan aquifer system (labelled as sub-region G by Krause and Randolph [36]). The approximate extent of this regional karst aquifer system throughout Florida and the southeastern coastal plain of Alabama, Georgia, and South Carolina and the submarine extent of the Floridan aquifer system in the Atlantic Ocean and Gulf of Mexico also is shown in Figure 1(a). County boundaries are political boundaries that have less influence on the location of panther dens than types of environmental boundaries. Figure 1(b) shows the location of the 12 sub-basins within the Greater Everglades Basin $(0$ - 11). These sub-basins cover the south sub-region of the Floridan aquifer system, but also extend into other sub-regions of the aquifer

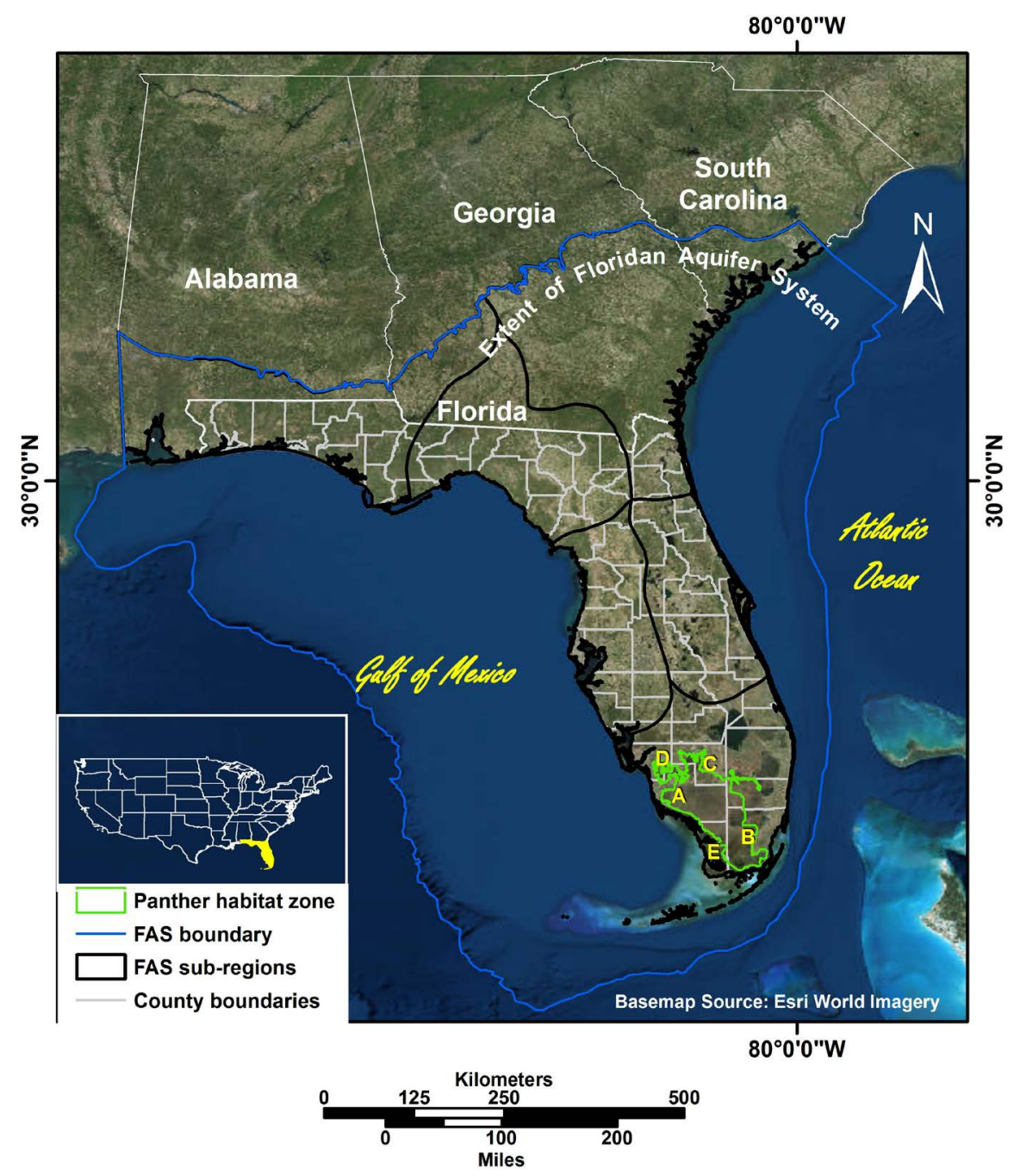

(a) 


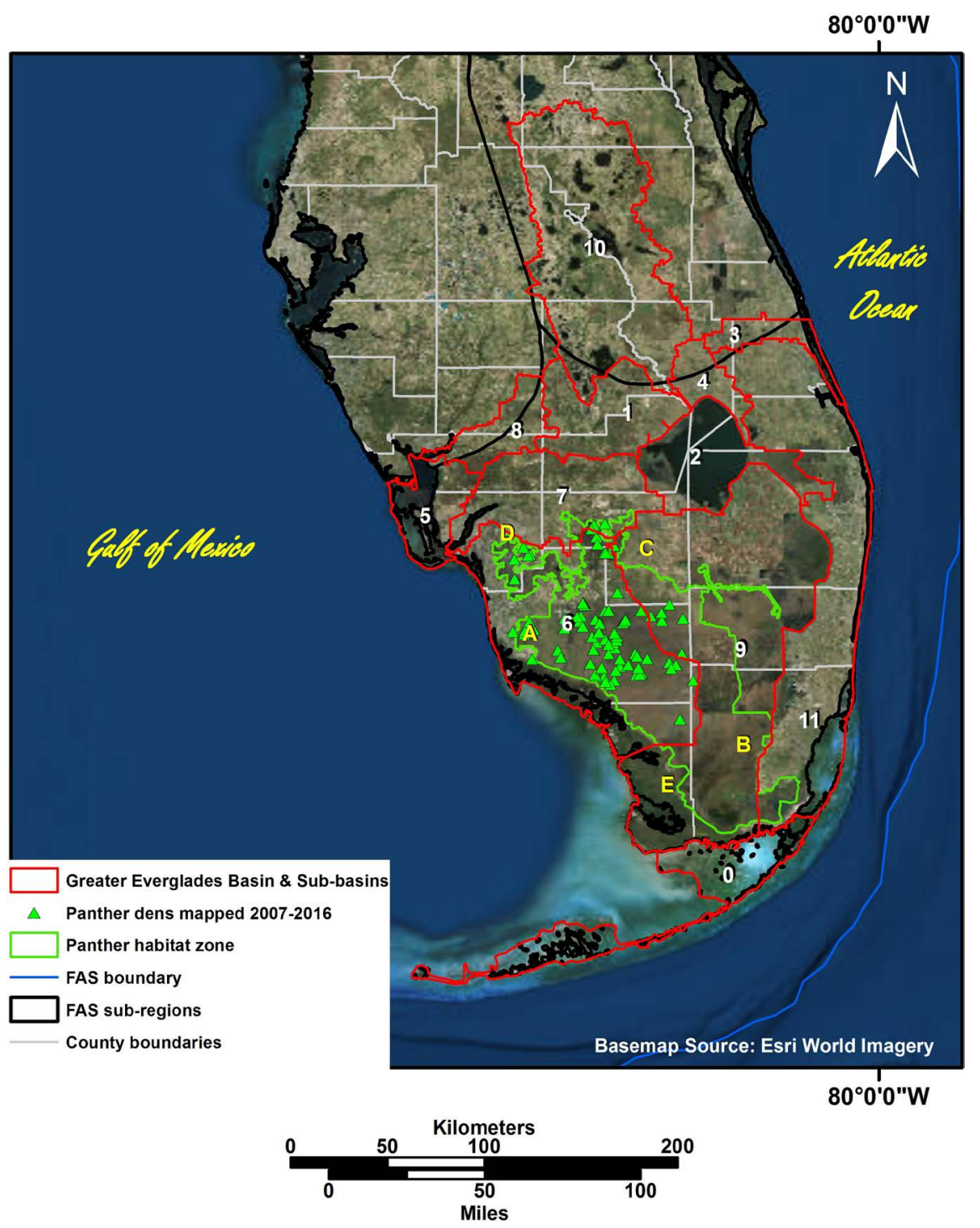

(b)

Figure 1. Proximity of the primary panther habitat zone in south Florida to: (a) Collier, Dade, Hendry, Lee, and Monroe Counties (A-E, respectively), approximate submarine extent of the Floridan aquifer system in the Atlantic Ocean and Gulf of Mexico, and the six sub-regions of the regional aquifer system throughout Florida and the southeastern coastal plain of Alabama, Georgia, and South Carolina; with insert showing location of Florida within the US, and (b) 93 panther dens from 2007-2016 in sub-basins 6, 7, and 9 of the 12 sub-basins in the Greater Everglades Basin (0 - 11).

\subsection{Proximity of Panther Dens to Mapped Fractures and Groundwater Withdrawal Wells}

Figure 2(a) shows the proximity of the 93 panther dens to fractures included in the ACOE Final Technical Data Report [34] in southern Florida, as well as the fractures mapped by the Remote Sensing staff of the FDOT [33]. The ACOE fracture dataset was confined primarily to the south Florida sub-region of the Floridan aquifer system, but also extended into sub-regions labelled as $\mathrm{E}$ and $\mathrm{F}$ 
by Krause and Randolph [36]. The FDOT fracture dataset covers the entire state and all six sub-regions of the aquifer system. Lake Okeechobee, in the center of south Florida, is notable because of the absence of lineaments representing fractures throughout the lake. This is because of the difficulty in detecting linear features within water bodies remotely, with aerial photography and satellite images used for those data sets. The absence of mapped lineaments throughout Lake Okeechobee does not imply that the mapped fractures do not extend through the entire extent of Lake Okeechobee. Figure 2(b) shows the locations of groundwater withdrawals wells, including aquifer storage and recovery (ASR) wells, permitted in the SFWMD and SWFWMD jurisdictions. These groundwater withdrawal wells are dense throughout all sub-basins except sub-basin 2 (Lake Okeechobee), which is open water. The SFWMD withdrawal wells appearing in the open water of Lake Okeechobee, the Gulf of Mexico, and the Atlantic Ocean are the result of errors in the recorded coordinates for those wells, rather than actual wells installed in open water.

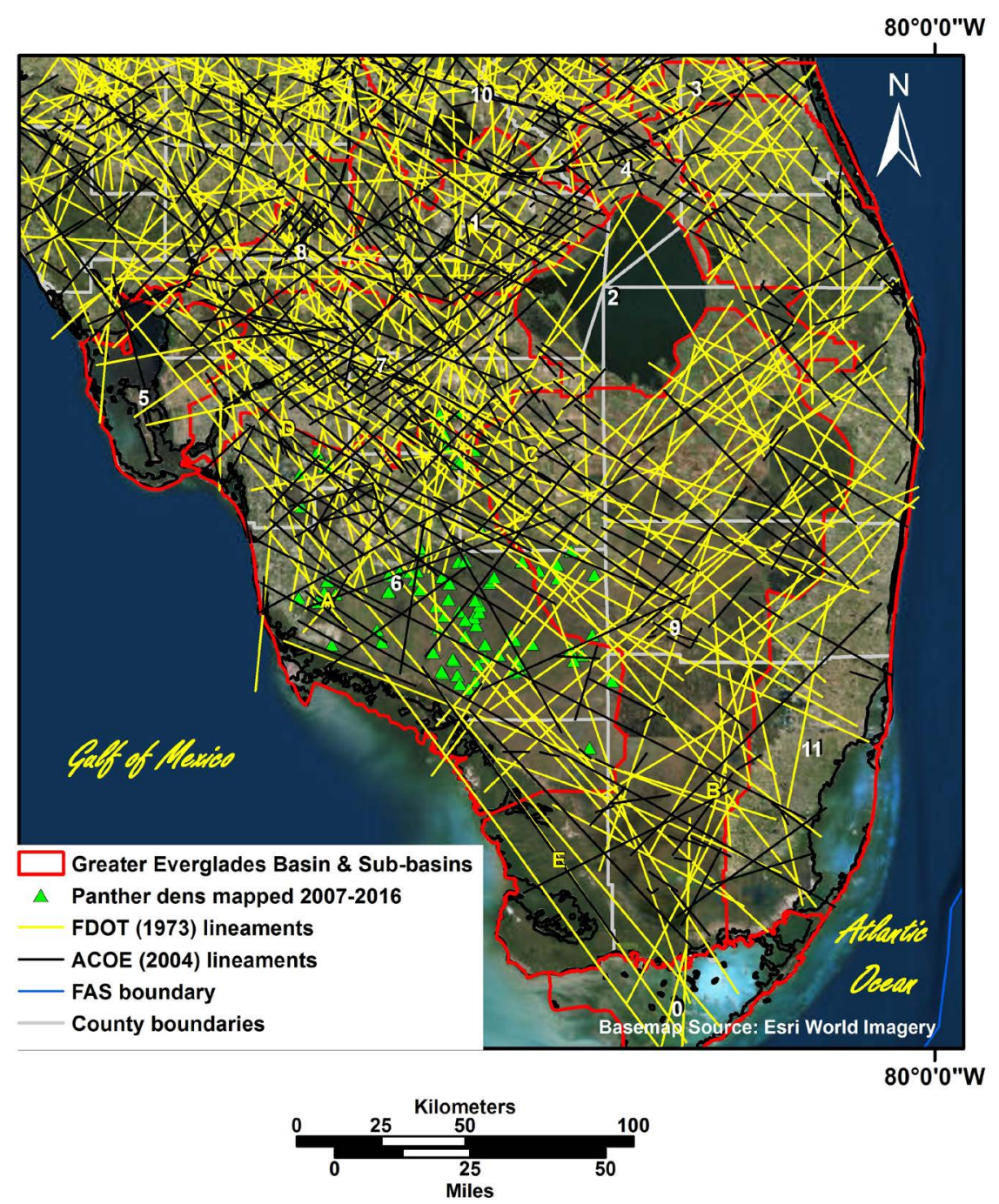

(a) 


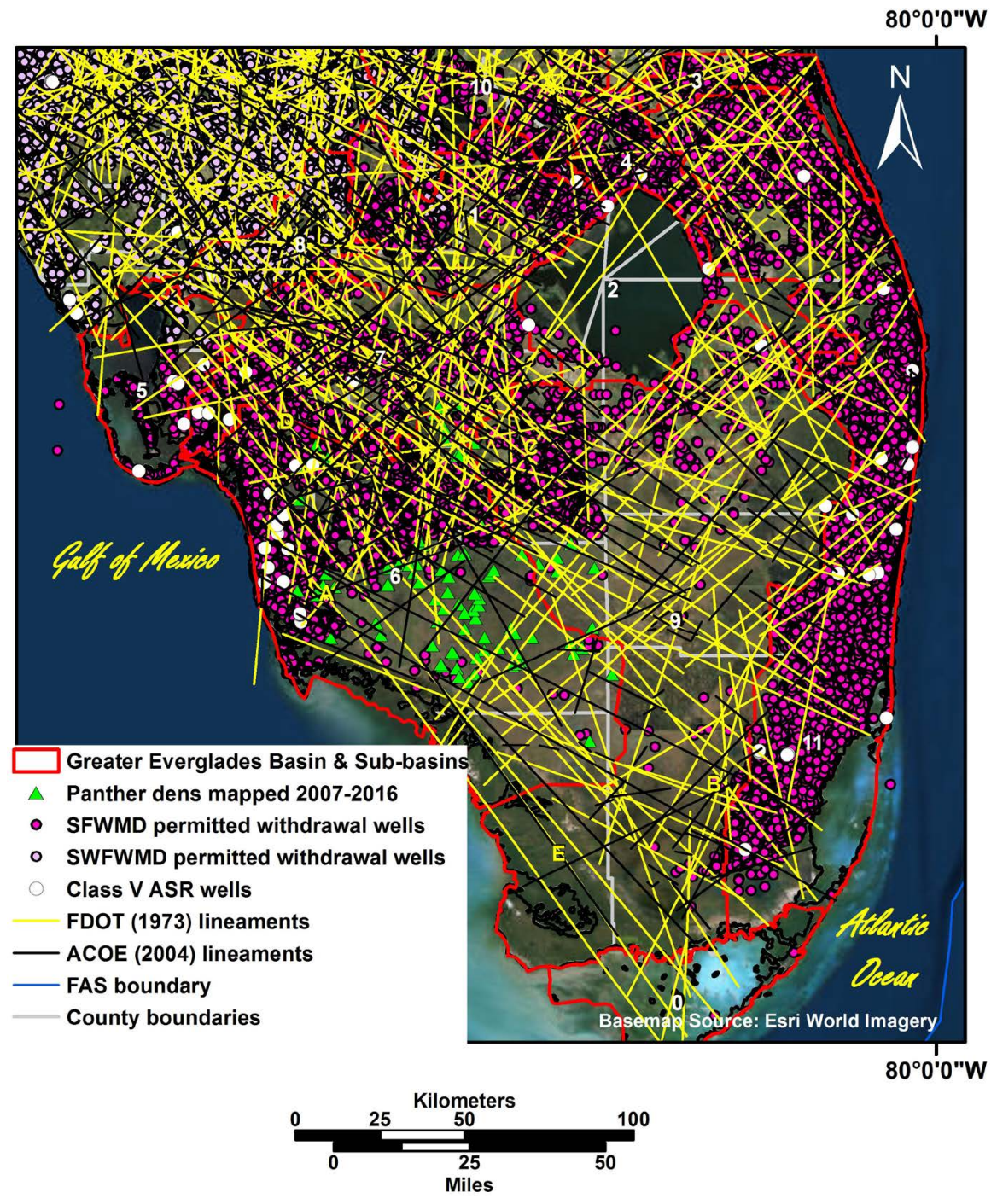

(b)

Figure 2. Proximity of 93 panther dens from 2007-2016 in south Florida to: (a) fractures in Florida reported by the ACOE [35] and mapped by FDOT [33], and (b) ASR and other groundwater withdrawal wells permitted by the SFWMD and SWFWMD (north of designated panther habitat).

\subsection{Number of Panther Dens and the Density, Frequency, and Length of Fractures and Fracture Intersections Mapped in the Five South-Florida Counties}

The total number of panther dens and the density of panther dens per $100 \mathrm{~km}^{2}$ mapped in each of the five counties in south Florida is shown in Table 1. The greatest number of panther dens occurred in Collier County (77) and the least number of dens occurred in Dade and Monroe Counties ( 1 each). The density of dens per $100 \mathrm{~km}^{2}$ from greatest to least were 2.3 (Monroe) $>1.5$ (Dade) $>0.2$ (Collier) $>0.0$ (Hendry and Lee).

Table 1 summarizes the total number of fractures and fracture intersections, density of fractures, and the shortest, longest, and mean fracture lengths previ- 
ously mapped in those five counties [33] [35]. The greatest density of fractures per $100 \mathrm{~km}^{2}$ from the ACOE (2004) dataset occurred in Monroe (2.4) and Collier (2.0) Counties. Those counties also included the greatest density of fractures per $100 \mathrm{~km}^{2}$ from the FDOT [33] dataset (1.7 each). The total number of fractures from the ACOE [35] dataset ranged from 75 in Monroe County to 11 in Lee County. The total number of intersections of fractures from the ACOE [35] dataset with other fractures from that dataset ranged from 90 in Collier County to 4 in Monroe County. The total number of fractures from the FDOT [33] dataset ranged from 51 in Monroe County to 23 in Lee County. The total number of intersections of fractures from the FDOT [33] dataset with other fractures from that dataset ranged from 296 in Hendry County to 22 in Monroe County. Table 1 also shows the results of both sets of fractures combined to determine the total number of fractures and fracture intersections in each county. The results for total combined fractures were Monroe (126) > Dade (100) > Collier (79) $>$ Hendry (68) > Lee (34). The results for all fracture intersections were Monroe (733) $>$ Dade (539) $>$ Collier (352) $>$ Hendry (232) $>$ Lee (51).

The shortest fractures mapped in those five counties were $2 \mathrm{~km}$ long for the ACOE [35] dataset and $21 \mathrm{~km}$ long for the FDOT [33] dataset. By comparison, the longest fractures mapped in those counties were $181 \mathrm{~km}$ for the ACOE [35] dataset and $311 \mathrm{~km}$ for the FDOT [33] dataset. Mean lengths for fractures reported by ACOE [35] were greatest for Lee County (50 km) and least for Monroe County $(30 \mathrm{~km})$. Mean lengths for fractures reported by FDOT [33] were greatest for Dade County $(134 \mathrm{~km})$ and least for Hendry County $(108 \mathrm{~km})$. Mean lengths of fractures from the FDOT [33] dataset were more than twice the length of fractures in the ACOE [35] dataset (Table 1).

Figure 3 provides a comparison of the length and frequency of mapped fractures (from ACOE [35] and FDOT [33]) in the five counties in south Florida where the 93 panther dens were reported. The scale of the $\mathrm{X}$ and $\mathrm{Y}$ axes are constant,

Table 1. Number of panther dens ${ }^{1}$, and density and frequency of fractures, fracture intersections, lengths of shortest and longest fractures, and mean fracture lengths for fractures ${ }^{2}$ reported by ACOE [35] and FDOT [33] in five south-Florida counties where 93 panther dens were mapped in 2007-2016.

\begin{tabular}{cccccccccccc}
\hline & No. of Dens & $\begin{array}{c}\text { No. of Fractures/ } \\
100 \mathrm{~km}^{2}\end{array}$ & \multicolumn{2}{c}{$\begin{array}{c}\text { Total No. of } \\
\text { Fractures/Intersect. }\end{array}$} & $\begin{array}{c}\text { Total Fractures/ } \\
\text { Intersect. }\end{array}$ & $\begin{array}{c}\text { Shortest-Longest } \\
\text { Fractures (km) }\end{array}$ & $\begin{array}{c}\text { Mean Fracture } \\
\text { Length }(\mathrm{km})\end{array}$ \\
\hline County & Total/100 $\mathrm{km}^{2}$ & ACOE & FDOT & ACOE & FDOT & & ACOE & FDOT & ACOE & FDOT \\
\hline Collier & $77 / 0.2$ & 2.0 & 1.7 & $43 / 90$ & $36 / 163$ & $79 / 352$ & $2-105$ & $26-311$ & 31 & 133 \\
Dade & $1 / 1.5$ & 1.0 & $0.9 /$ & $53 / 18$ & $47 / 100$ & $100 / 539$ & $4-181$ & $28-310$ & 43 & 134 \\
Hendry & $9 / 0.0$ & 0.6 & $0.7 /$ & $32 / 84$ & $36 / 296$ & $68 / 232$ & $2-181$ & $21-310$ & 33 & 108 \\
Lee & $5 / 0.0$ & 0.4 & $0.9 /$ & $11 / 41$ & $23 / 118$ & $34 / 51$ & $4-181$ & $41-311$ & 50 & 115 \\
Monroe & $1 / 2.3$ & 2.4 & 1.7 & $75 / 4$ & $51 / 22$ & $126 / 733$ & $3-147$ & $28-311$ & 30 & 122 \\
\hline Totals & 93 & & & & & & $2-147$ & $21-311$ & \\
\hline
\end{tabular}

${ }^{1}$ from Florida Panther Project; ${ }^{2}$ from ACOE (2004) and FDOT (1973). 


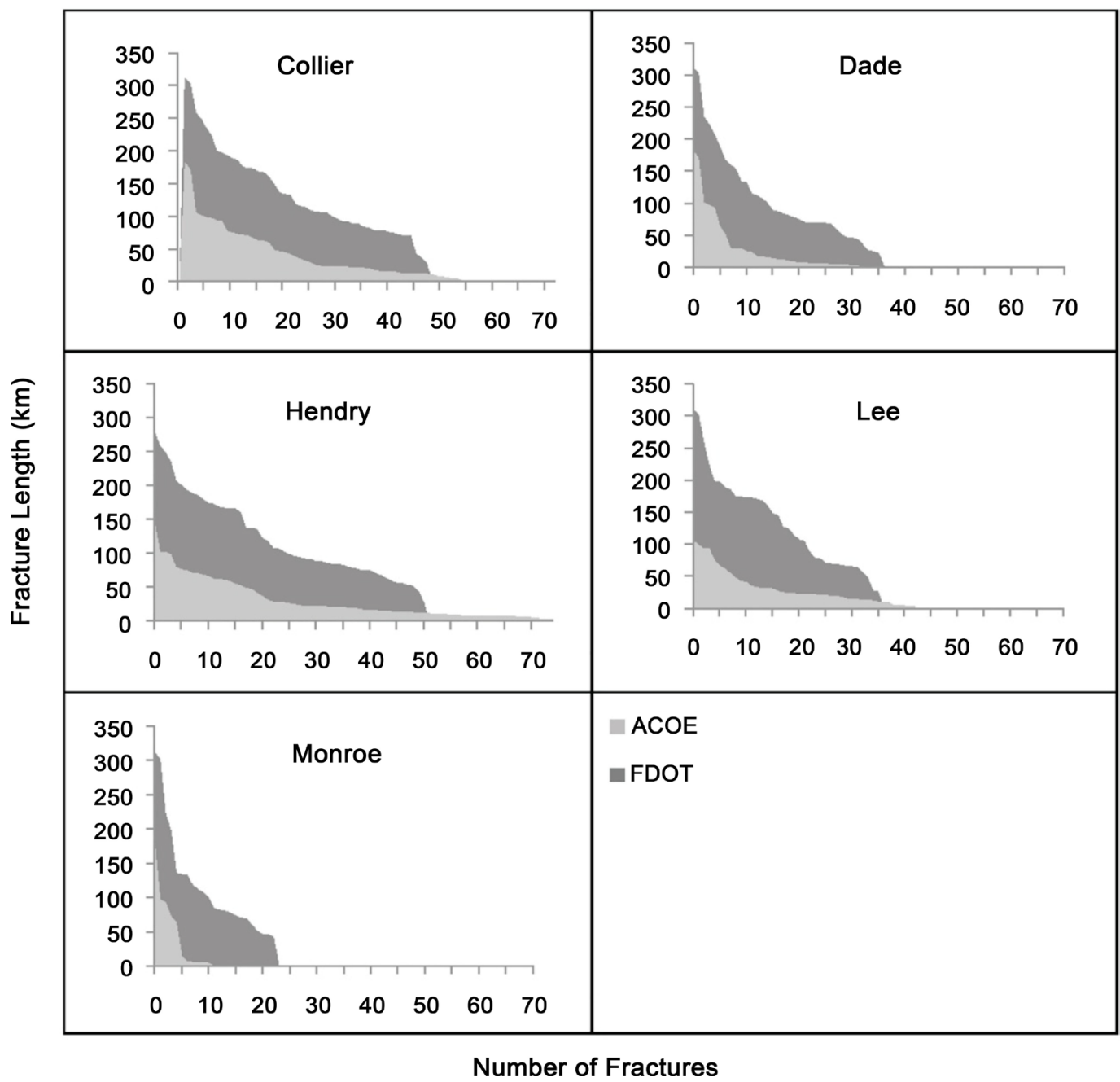

Figure 3. Fracture lengths and frequencies from ACOE [35] and FDOT [33] datasets in five south Florida counties where 93 panther dens were located in 2007-2016.

with a maximum of 70 fractures and $350 \mathrm{~km}$, respectively. The length of fractures in the FDOT [33] dataset is approximately twice the length of fractures in the ACOE [35] dataset for all five counties. The number of fractures in the FDOT [33] dataset exceeds the number of fractures in the ACOE [35] dataset for Dade and Monroe Counties. The greatest number of fractures in the ACOE [35] dataset occurred in Hendry County.

Figure 4(a) provides the results of our analysis of the nearest fracture from the ACOE [35] and FDOT [33] datasets, separately, and to the nearest fracture in either dataset to each panther den. Of the 93 dens, $36 \%$ and $74 \%$ were within $1 \mathrm{~km}$ and $2 \mathrm{~km}$ of previously mapped fractures, respectively. The remaining dens were located within $5 \mathrm{~km}$ of at least one of those previously mapped fractures. Analysis of the nearest fracture from either dataset was equivalent to the number of dens closest to fractures in the ACOE [35] dataset for all distance intervals from $0-2 \mathrm{~km}$, except for $1 \mathrm{~km}$. The distances from dens to the nearest intersection of fractures from either data set also were evaluated (Figure 4(b)). Of the 93 


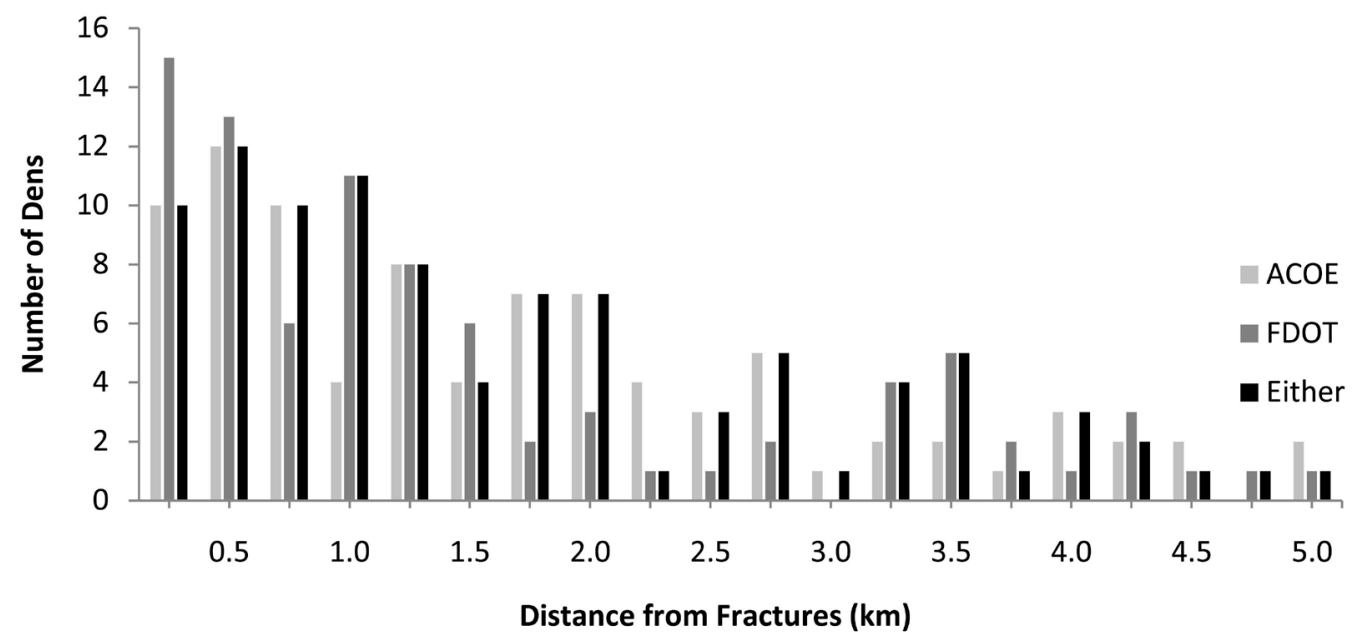

(a)

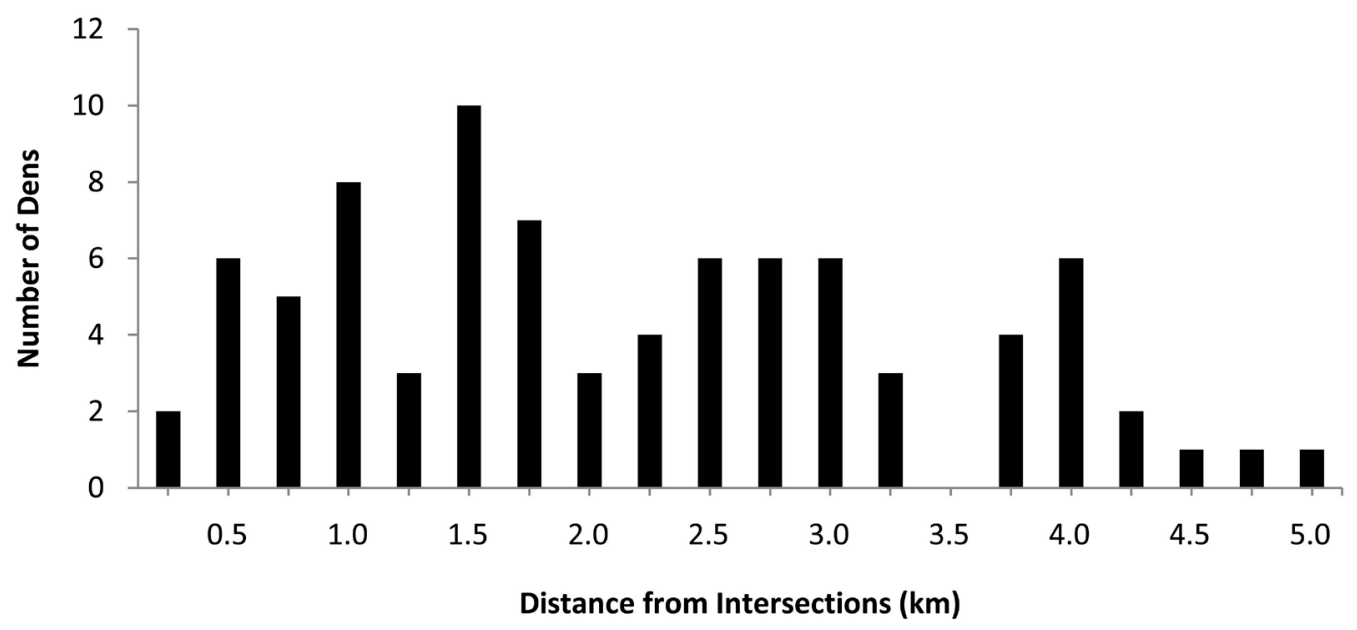

(b)

Figure 4. Distances from 93 panther dens located in south Florida from 2007-2016 to the nearest: (a) fracture mapped in the same vicinity for the ACOE [35], FDOT [33], and either data set; and (b) fracture intersections for the combined fracture data sets.

dens, 44 dens (47\%) and 69 dens (74\%) occurred within $2 \mathrm{~km}$ and $3.25 \mathrm{~km}$, respectively, of a fracture intersection, and $84(90 \%)$ were within $5 \mathrm{~km}$ of a fracture intersection.

\section{Discussion and Conclusions}

\subsection{Potential Effects of Groundwater and Other Mining on Panther Habitat}

The Introduction describes the impact of groundwater mining in Florida for industrial, municipal and agricultural use on habitat, which includes both wetland and upland habitat required for the survival and recovery of panthers. That groundwater mining results in threats to water resources by increasing saltwater intrusion into the aquifer system and resulting in other forms of water quality degradation, sinkholes, and induced recharge to the aquifer from the overlying 
surficial aquifers. Bacchus [25] [26] [27] [37] [38] [39], Bacchus and Barile [40], Bacchus and Brook [41], Bacchus et al. [28] [29] [30] [42] [43] [44], Bernardes et al. [45], Cunningham et al. [46], Fitterman and Deszcz-Pan [47], Hofstetter and Sonenshein [48], Lines et al. [24], Maslia and Prowell [49], McNeill [50], Odum et al. [51], Patten and Klein [52], Price and Pichler [53], Renken et al. [54], Sonenshein and Hofstetter [55], and Wilcox et al. [56] provide examples of adverse environmental impacts throughout the extent of the Floridan aquifer system associated with induced recharge and other pirated water from aquifer withdrawals (mechanical and nonmechanical) and injections, including ASR. Categories of these adverse impacts include: 1 ) depletion of groundwater reserves; 2 ) intrusion of water of undesirable quality (e.g., lateral saltwater intrusion, upconing of brackish and saline water through fractures and other karst conduits, and contaminants such as arsenic and benzene); 3) contravention of existing water rights; 4) excessive depletion of streamflow by induced infiltration/recharge; 5) land subsidence (e.g., "reactivating" relict sinkholes by increasing flow through infilled sediments and debris); 6) reductions of levels and/or extent of lakes and wetlands, invasion of alien/nuisance species and premature decline and death of trees from insects and pathogens, with consequent loss of valued habitat; 7) reductions in extent of areas where water is available to plants that use the capillary fringe, followed by catastrophic destructive wildfires and loss of habitat; and 8) reductions of groundwater outflow to coastal waters, with consequent impacts to coastal wetlands and/or nearshore benthic marine habitats [57]. Bacchus [26] provided photographs of irreversible damage to depressional wetlands after catastrophic wildfires caused by unsustainable groundwater withdrawals.

As one agricultural example of these adverse environmental impacts from groundwater mining, Florida is the largest US producer of winter strawberries and the most common form of protection of the strawberries from frost-freeze events is sprinkler irrigation of large volumes of water pumped from the aquifer to form a layer of insulating ice over the plants. This pumping degrades water quality, causes water shortages and sinkholes, and threatens sustainability of the water resource and habitat. The analysis of two severe frost-freeze events from 1985 and 2010, in west central Florida's 25-year irrigation for winter-strawberry production north of the breeding range of the Florida panther, showed that spatial distribution of sinkholes was non-random [58], linking those sinkholes to the irrigation. Wilcox et al. [56] estimated the volume of water being diverted from wetlands in the Everglades National Park by municipal wellfields, directly and indirectly, by using isotopic analysis of the water, but did not assess the damage to wetlands in the National Park from that pirated water.

We obtained the telemetry data for the movement of two female panthers with dens, identified as 09 and 11 and evaluated by Maehr et al. [11]. We evaluated the telemetry data for those two panthers to provide information regarding movements and reproduction success of female panthers with dens related to fracture locations. Figure 5 displays those panther location points as a GIS layer 

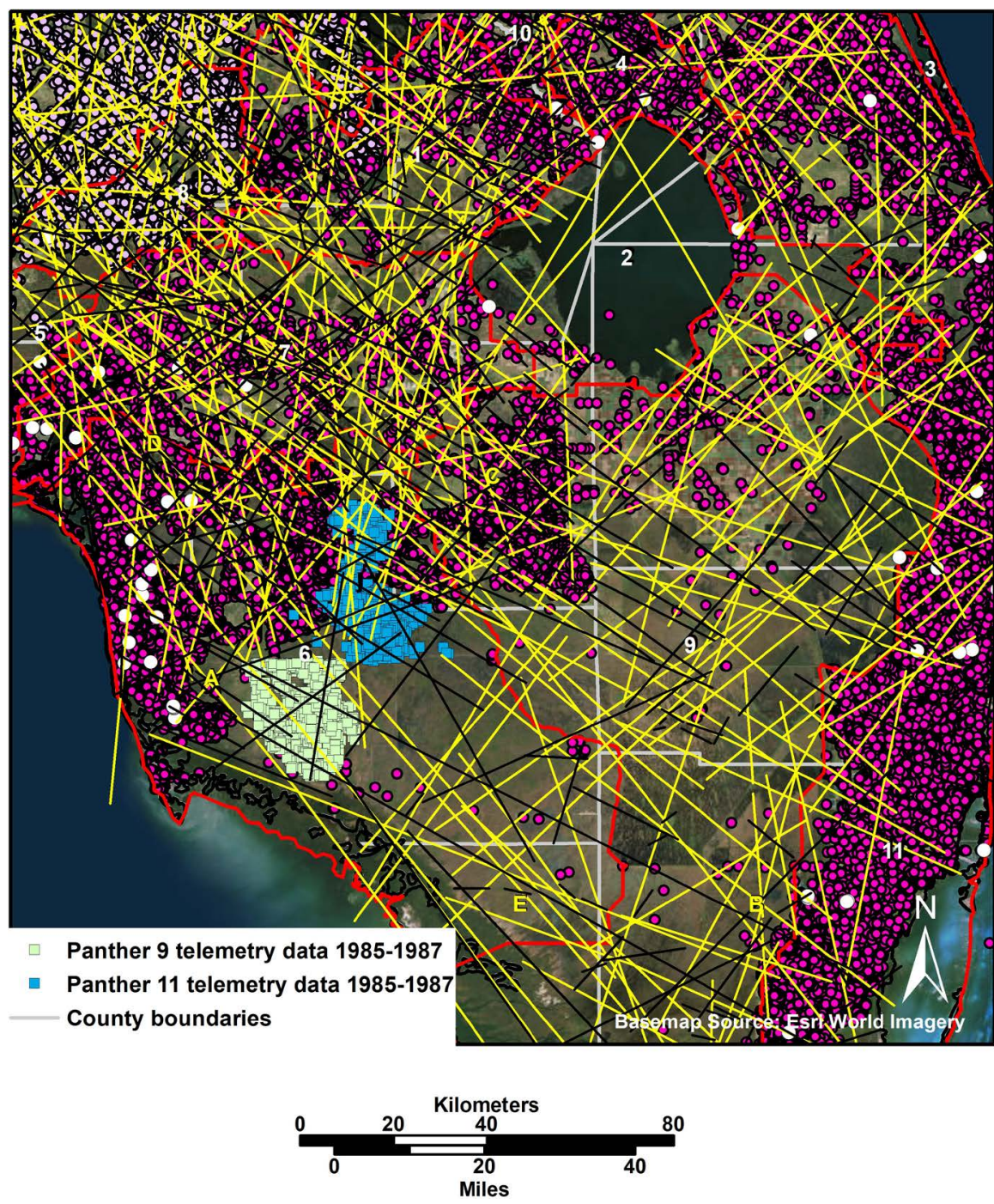

Figure 5. Proximity of telemetry locations for movements from 1985-1987 of female panthers 09 and 11 with dens [11] to fractures in Florida reported by ACOE [35] and mapped by FDOT [33], and ASR and other groundwater withdrawal wells permitted by the SFWMD and SWFWMD (symbols other than telemetry locations are the same as in Figure 2).

combined with the locations of the two datasets of previously mapped fractures [33] [35] and the withdrawal wells, including ASR wells, permitted in that area. The abrupt horizontal southern and northern extent of those location points for panthers 09 and 11, respectively, presumably resulted from the multi-lane, high-speed Interstate 75 (I-75) for east/west traffic across south Florida. An extensive, tall chain-link fence was constructed along the north and south sides of that portion of I-75 in an attempt to prevent access of large animals, such as panthers, to the interstate where they could be killed by collisions with vehicles. That fenced interstate partially bifurcates the panther habitat into north and south segments in that area.

There are no withdrawal wells obscured by the location points for panther 11 
and only two ACOE [35] fractures and five FDOT [33] fractures intersect that cluster of location points. In contrast, there are extensive withdrawal wells, including many obscured by the panther-location points, and fractures throughout the cluster of location points for panther 09 . Additionally, the cluster of location points for panther 09 also is intersected by a fracture associated with the ASR well on the north shore of Lake Okeechobee and other fractures associated with 13 ASR wells located southwest of the 09 cluster.

\subsection{Deficiencies in Previous Studies of Vegetation Characteristics at Panther Den Sites}

As illustrated in the Introduction, most of the previous studies of panther den sites have focused on some aspect of vegetation characteristics, but have not considered the influence of fractures on vegetation. According to Maehr et al. [11], the den site for panther 09 in their study of early maternal behaviour in the Florida panther was located at the edge of a live oak hammock in a dense thicket of grape vines (Vitis spp.), wax myrtle and swamp dogwood. Vegetation indicators of aquifer fractures include live oaks (S.T. Bacchus unpublished data) [24]. Swamp dogwood is indicative of wetlands [59], and dense thickets of native grape vines and wax myrtle are indicators of drawdowns in surficial aquifers overlying the Floridan aquifer system resulting from groundwater and other mining (S.T. Bacchus unpublished data) [60]. The habitats and plant species reported for panther 09 are more susceptible to those types of groundwater alterations than upland habitats with dense saw palmetto thickets $1-2 \mathrm{~m}$ tall, where the den site of panther 11 was located in the study by Maehr et al. [11]. Therefore, that specific information of plant species and density, combined with the knowledge of fractures and withdrawal wells provide additional support for the conclusion that groundwater alterations may have been a key factor for the location and reproductive success of those panthers. For example, panther 09 may have been forced to choose a den site with dense vegetation responding to hydroperiod alterations, which also decreased the quality of the surrounding habitat for suitable prey required for the survival of her kittens. Conversely, panther 11 may have had access to naturally dense native vegetation unaffected by hydroperiod alterations for her den site, with equally suitable native habitat to support prey essential for raising three kittens.

Compared to the cluster of location points for panther 11 from Maehr et al. [11], more previously mapped fractures and permitted withdrawal wells, including ASR wells, are associated with the cluster of location points for panther 09 (Figure 5). That suggests groundwater alterations may have been a key factor in the "lower nutritional plane" discussed by Maehr et al. [11], as possibly the most important factor influencing the lower number of surviving kittens and larger home range for panther 09. In fact, groundwater alterations may have been the key factor in the inabilitiy of panther 09 to rear more than one kitten, while panther 11 successfully reared at least three kittens. 
In their evaluation of natal den selection by female Florida panthers, Benson et al. [19] referenced the belief of Litvaitis et al. [61] that animals require four main environmental components for life: food, water, cover, and denning or nesting sites. Unfortunately their evaluation of natal den selection included several unfounded assumptions. They evaluated potential edge effect in the eight habitat types designated in that study and assumed that all of the habitat in each of those cover types was representative of the designated cover type. That assumption is not valid for any habitat type overlying the Floridan aquifer system because induced recharge and saltwater intrusion occurs preferentially along fractures in that karst aquifer system. The magnitude of adverse impacts for wetland and upland habitat types associated with fractures (e.g., pond-cypress wetlands, wet prairies, and live oak hammocks) will be greater where groundwater alterations are associated with those fractures. Natural depressional wetlands characteristic of the Floridan aquifer system (e.g., pond-cypress wetlands and wet prairies) occur in relict sinkholes that are aligned along fractures and connected to the underlying regional karst aquifer system [25] [26] [27] [28] [30] [31] [37] [43]. Wise et al. [62] acknowledged the hydraulic connectivity (i.e., hydrologic connection) of the aquifer and natural depressional wetlands in Florida, but erroneously referred to those wetlands as "isolated wetlands." This is important in confirming that those wetlands cannot be recreated at random locations as some mitigation or no net loss scheme, because the function of those wetlands depends on their interaction with fractures. That suggests groundwater alterations of those natural habitats (cover types) may be a factor influencing habitat preferences in that study and all of the studies of habitat preferences for panther dens and foraging.

Another unfounded assumption in Benson et al. [19] was that because most dens $(>90 \%)$ and home ranges used in the analyses were located on public or Seminole Indian Reservation lands, changes to the habitat types were minimal. The surface boundaries of those public and reservation lands do not extend underground. Therefore, those boundaries are not barriers to the saltwater intrusion, induced recharge, and concomitant invasive plant species, as well as catastrophic, destructive wildfires from altered hydroperiods and increased salinity due to preferential flow through fractures in the Floridan aquifer system in response to groundwater and other types of mining [26] [27] [28] [30] [31] [37] [43] [60]. Consequently, adverse changes to habitat types in both public lands and the Seminole Indian Reservation lands within the breeding range of panthers can be and have been significant. Maehr et al. [11] reported observations of panther 11 during a successful deer-hunting foray in June, after travelling $4 \mathrm{~km}$ across a large herbaceous marsh to a larger island with saw palmetto, slash pine (Pinus elliotii), cypress (Taxodium distichum), and red maple (Acer rubrum). The cypress referenced in that study probably was pond-cypress ( $T$. ascendens), rather than bald-cypress ( $T$. distichum), because of the associated plant species referenced by Maehr et al. [11] and the fact that pond-cypress originally was 
considered a sub-species of $T$. distichum until the definitive taxonomic description by Godfrey [59] of pond-cypress as a distinct species in a distinctly different habitat (i.e., depressional wetlands) from bald-cypress (i.e., stream systems).

Additionally, Benson et al. [19] assumed that the temporal difference between panther locations and landcover data of $\leq 3$ years for each den in their analysis was insignificant. Significiant adverse changes can occur in both density and quality of habitat type in less than that time from alterations associated with fractures, as described previously. Benson et al. [19] also assumed that habitat-type changes due to natural succession events would not occur within their data-collection time frame. Although that may be true for natural succession events, unnatural succession events can occur much more rapidly in response to anthropogenic groundwater alterations. One example of such a result is catastrophic, destructive wildfires from anthropogenic hydroperiod alterations. Those fires change species composition, density, and habitat within broad cover types. Changes occur because fire-adapted trees and native understory vegetation are killed when the roots are exposed and burned due to oxidation, ignition, and consumption of the organic soils, or the roots no longer have access to groundwater during times of low rainfall [26]. Those types of fires can convert desirable habitat for panther dens and prey species to cattail marshes (S.T. Bacchus, unpublished data). Benson et al. [19] identified cattail marshes as a cover type avoided by female panthers for den sites and prey habitat. Unfortunately, that study combined cattail marshes with two other habitat types from the original land cover (i.e., freshwater marsh and wet prairie, and sawgrass marsh) into one habitat type (i.e., freshwater marsh-wet prairie). That combination may have influenced the results and conclusions of that study and other studies combining those cover types because cattail marshes generally result from anthropogenic alterations of natural hydroperiods and eutrophication, while sawgrass marshes (also known as marl prairies) and wet praires are natural ecosystems (S.T. Bacchus, unpublished data) [63].

\subsection{Conservation Implications}

Habitat alterations from groundwater and other mining associated with previously mapped fractures in the Floridan aquifer system, due to preferential flow referenced in our study, can occur many kilometers from the surface footprint of the sources of those alterations. The results of our study documented the proximity of 93 panther dens identified in 2007-2016 by the Florida Panther Project and telemetry locations for panthers 09 and 11 from Maehr et al. [11] to fractures throughout habitat in the primary panther zone habitat in south Florida. In addition to confirming that those dens and telemetry locations are located near previously mapped fractures, our results also suggest that plant species composition and vegetation density of both wetland and upland habitats may influence the suitability of habitat for panther dens, panther selection of den sites, and the availability, and abundance of high quality prey items essential to meet the nutritional demands of successfully rearing panther kittens in the wild. 
These specific findings imply that the remaining habitat suitable for panther den sites and the successful raising of young panthers is much smaller than the existing areas designated as primary and secondary panther habitat, which is based on vegetation and human-related factors considered in previous studies. Thus, that panther habitat may not be able to sustain the Florida panther. Our findings also suggest that land use and groundwater withdrawals beyond the boundaries of designated panther habitat should be considered in the management of the Florida panthers' ecosystem. Similar findings may be expected for habitats and ecosystems associated with fractured aquifer systems worldwide and may be exacerbated by global climate change.

The significance of our findings is emphasized because decisions determining the management, restoration and acquisition of habitat, including habitat for Florida panthers, generally depend on interpretations by land managers of how wildlife selects habitat [22]. Our results suggest that the model developed by Frakes et al. [7], for use by conservation agencies attempting to identify and protect the most valuable panther habitat in south Florida, should be modified to consider the influence of fractures on identifying and protecting habitat for the federally endangered Florida panther. This conclusion is supported by the fact that their model showed that hydrology is one of the most important factors determining the presence of adult panthers. Therefore, we recommend more detailed investigations of: a) vegetation characteristics associated with panther dens and the movements of female Florida panthers while raising kittens; b) groundwater alterations associated with fractures in the vicinity of panther habitat in south Florida; c) cumulative impacts of groundwater and other mining on plant species composition and density in panther habitat zones; and d) considerations of fracture impacts on all habitats underlain by karst and other fractured aquifer systems worldwide.

\section{Acknowledgements}

We are grateful for the comments of Dr. Eleanora Robbins and anonymous reviewers that resulted in significant contributions to our final manuscript. We also thank Dave Onorato, Research Scientist for the Florida Panther Project, Fish and Wildlife Research Institute, Florida Fish and Wildlife Conservation Commission, for providing access to the Florida Panther Project data for 93 Florida panther dens from 2007-2016 and for telemetry data for panthers 09 and 11 for behavior patterns associated with rearing of kittens during the first 6 months after parturition (January 1985 through December 1987), evaluated by Maehr et al. [11]. Our research was not destructive, did not violate conservation research ethics, and did not receive any specific grant from funding agencies in the public, commercial, or not-for-profit sectors.

\section{References}

[1] Back, W., Rosenshein, J.S., Seaber, P.R. and Decade of North American Geology Project (1988) Hydrogeology. Geological Society of America, Boulder. 
[2] Borchers, J.W. (1998) Land Subsidence: Case Studies and Current Research. In: Borchers, J.W., Ed., Proceedings of the Dr. Joseph F. Poland Symposium on Land Subsidence, Star Publishing, Belmont, 576.

[3] Ford, D. and Williams, P.W. (1989) Karst Geomorphology and Hydrology. Unwin Hyman, London/Boston. https://doi.org/10.1007/978-94-011-7778-8

[4] Poland, J.F.E. (1984) Guidebook to Studies of Land Subsidence Due to Groundwater Withdrawal. International Hydrological Programme-Working Group 8.4, United Nations Educational, Scientific and Cultural Organization (UNESCO), Paris.

[5] Sahoo, S., Das, P., Kar, A. and Dhar, A. (in press) A Forensic Look into the Lineament, Vegetation, Groundwater Linkage: Study of Ranchi District, Jharkhand (India). Remote Sensing Applications: Society and Environment.

[6] Stanford, J.A. and Valett, H.M. (1994) Proceedings of the 2nd International Conference on Ground Water Ecology, Herndon, 27-30 March 2004, 390 p.

[7] Frakes, R.A., Belden, R.C., Wood, B.E. and James, F.E. (2015) Landscape Analysis of Adult Florida Panther Habitat. PLoS ONE, 10, e0133044.

https://doi.org/10.1371/journal.pone.0133044

[8] Young, S.P. and Goldman, E.A. (1946) The Puma, Mysterious American Cat. The American Wildlife Institute, Washington DC.

[9] United States Fish and Wildlife Service (1988) Florida Panther (Felis concolor coryi) Recovery Plan. U.S. Fish and Wildlife Service, Atlanta.

[10] Roelke, M.E. (1987) Panther Health and Reproduction. Florida Game and Fresh Water Fish Game Commission, Tallahassee.

[11] Maehr, D.S., Land, E.D., Roof, J.C. and McCown, J.W. (1989) Early Maternal-Behavior in the Florida Panther (Felis concolor coryi). American Midland Naturalist, 122, 34-43. https://doi.org/10.2307/2425680

[12] Denny, A.H. (1944) Wildlife Relationships to Soil Types. Transactions of the North America Wildlife Conference, 9, 316-322.

[13] Harlow, R.F. and Jones, F.K.J. (1965) The White-Tailed Deer in Florida. Florida Game and Fresh Water Fish Commission, Tallahassee.

[14] Belden, R.C. and Maehr, D.S. (1986) Florida Panther Food Habits. Study E-1-10, Annual Performance Report, Florida Game and Fresh Water Fish Commission, Tallahassee.

[15] Hemker, T.P., Lindzey, F.G. and Ackerman, B.B. (1984) Population Characteristics and Movement Patterns of Cougars in Southern Utah. The Journal of Wildlife Management, 48, 1275-1284. https://doi.org/10.2307/3801788

[16] Beier, P., Choate, D. and Barrett, R.H. (1995) Movement Patterns of Mountain Lions during Different Behaviors. Journal of Mammalogy, 76, 1056-1070. https://doi.org/10.2307/1382599

[17] Davis, J.H. (1943) The Natural Features of Southern Florida. Florida Geological Survey, Tallahassee.

[18] Emmons, L.H. (1988) A Field-Study of Ocelots (Felis pardalis) in Peru. Revue D’Ecologie-La Terre Et La Vie, 43, 133-157.

[19] Benson, J.F., Lotz, M.A. and Jansen, D. (2008) Natal Den Selection by Florida Panthers. Journal of Wildlife Management, 72, 405-410. https://doi.org/10.2193/2007-264

[20] Blanco, A. (2009) The Effect of Fire on Florida Panther (Puma concolor coryi) Den Site Selection. MSc Thesis, Florida Gulf Coast University, Fort Myers. 
[21] Land, E.D., et al. (2008) Florida Panther Habitat Selection Analysis of Concurrent GPS and VHF Telemetry Data. Journal of Wildlife Management, 72, 633-639. https://doi.org/10.2193/2007-136

[22] Onorato, D.P., et al. (2011) Habitat Selection by Critically Endangered Florida Panthers across the Diel Period: Implications for Land Management and Conservation. Animal Conservation, 14, 196-205. https://doi.org/10.1111/j.1469-1795.2010.00415.x

[23] van de Kerk, M., et al. (2015) Hidden Semi-Markov Models Reveal Multiphasic Movement of the Endangereds Florida Panther. Journal of Animal Ecology, 84, 576-585. https://doi.org/10.1111/1365-2656.12290

[24] Lines, J.P., et al. (2012) Preferential Groundwater Flow Pathways and Hydroperiod Alterations Indicated by Georectified Lineaments and Sinkholes at Proposed Karst Nuclear Power Plant and Mine Sites. Journal of Sustainable Development, 5, 78. https://doi.org/10.5539/jsd.v5n12p78

[25] Bacchus, S.T. (1998) Determining Sustainable Yield in the Southeastern Coastal Plain: A Need for New Approaches. In: Borchers, J.W., Ed., Proceedings of the Dr. Joseph F. Poland Symposium on Land Subsidence, Star Publishing, Belmont, 503-519.

[26] Bacchus, S.T. (2007) More Inconvenient Truths: Wildfires and Wetlands, SWANCC and Rapanos. National Wetlands Newsletter, 29, 15-21.

[27] Bacchus, S.T. (2006) Nonmechanical Dewatering of the Regional Floridan Aquifer System. Perspectives on Karst Geomorphology, Hydrology, and Geochemistry, 404, 219-234. https://doi.org/10.1130/2006.2404(18)

[28] Bacchus, S.T., Masour, J., Madden, M., Jordan, T. and Meng, Q. (2011) Geospatial Analysis of Depressional Wetlands near Peace River Watershed Phosphate Mines, Florida, USA. Environmental and Engineering Geoscience, 17, 391-415. https://doi.org/10.2113/gseegeosci.17.4.391

[29] Bacchus, S.T., Bernardes, S., Jordan, T. and Madden, M. (2014) Benthic Macroalgal Blooms as Indicators of Nutrient Loading from Aquifer-Injected Sewage Effluent in Environmentally Sensitive Near-Shore Waters Associated with the South Florida Keys. Journal of Geography and Geology, 6, 164-198. https://doi.org/10.5539/jgg.v6n4p164

[30] Bacchus, S.T., Bernardes, S., Xu, W. and Madden, M. (2015a) Fractures as Preferential Flowpaths for Aquifer Storage and Recovery (ASR) Injections and Withdrawals: Implications for Environmentally Sensitive Near-Shore Waters, Wetlands of the Greater Everglades Basin and the Regional Karst Aquifer System. Journal of Geography and Geology, 7, 117-155.

[31] Bacchus, S.T., Bernardes, S., Xu, W. and Madden, M. (2015b) What Georgia Can Learn from Aquifer Storage and Recovery (ASR) in Florida. Proceedings of the 2015 Georgia Water Resources Conference, Athens, 28-29 April 2015, 1-9.

[32] Stewart, M. and Langevin, C. (1999) Post Audit of a Numerical Prediction of Wellfield Drawdown in a Semiconfined Aquifer System. Ground Water, 37, 245-252. https://doi.org/10.1111/j.1745-6584.1999.tb00980.x

[33] Florida Department of Transportation (1973) Map of Lineaments in the State of Florida. Florida Department of Transportation, Tallahassee.

[34] United States Army Corps of Engineers (2014) Central and Southern Florida Project Comprehensive Everglades Restoration Plan: Vol. 2-Final Environmental Impact Statement-Lake Okeechobee ASR Pilot Project, Hillsboro ASR Pilot Project, 
Caloosahatchee (C-43) River ASR Pilot Project. US Army Corps of Engineers, Jacksonville.

[35] United States Army Corps of Engineers (2004) Lineament Analysis, South Florida Region. Draft Technical Memorandum Prepared by the USACE-SAJ. US Army Corps of Engineers, Jacksonville.

[36] Krause, R.E. and Randolph, R.B. (1989) Hydrology of the Floridan Aquifer System in Southeast Georgia and Adjacent Parts of Florida and South Carolina. US Geological Survey.

[37] Bacchus, S.T. (2000) Uncalculated Impacts of Unsustainable Aquifer Yield Including Evidence of Subsurface Interbasin Flow. Journal of the American Water Resources Association, 36, 457-481. https://doi.org/10.1111/j.1752-1688.2000.tb04279.x

[38] Bacchus, S.T. (2001) Knowledge of Groundwater Responses-A Critical Factor in Saving Florida's Threatened and Endangered Species. Part I: Marine Ecological Disturbances. Endangered Species Update, 18, 79-90.

[39] Bacchus, S.T. (2002) The "Ostrich" Component of the Multiple Stressor Model: Undermining South Florida. In: Porter, J.W. and Porter, K.G., Eds., The Everglades, Florida Bay, and Coral Reefs of the Florida Keys-An Ecosystem Sourcebook, CRC Press, Boca Raton, 677-748.

[40] Bacchus, S.T. and Barile, P.J. (2005) Discriminating Sources and Flowpaths of Anthropogenic Nitrogen Discharges to Florida Springs, Streams and Lakes. Environmental and Engineering Geoscience, 11, 347-369. https://doi.org/10.2113/11.4.347

[41] Bacchus, S.T. and Brook, G.A. (1996) Geophysical Characterization of Depressional Wetlands: A First Step for Determining Sustainable Yield of Groundwater Resources in Georgia's Coastal Plain. University of Georgia in Cooperation with the Environmental Resources Center-Georgia Institute of Technology, Atlanta, 36.

[42] Bacchus, S.T., Hamazaki, T., Britton, K.O. and Haines, B.L. (2000) Soluble Sugar Composition of Pond-Cypress: A Potential Hydroecological Indicator of Groundwater Perturbations. Journal of the American Water Resources Association, 36, 55-65. https://doi.org/10.1111/j.1752-1688.2000.tb04248.x

[43] Bacchus, S.T., et al. (2003) Near Infrared Spectroscopy of a Hydroecological Indicator: New Tool for Determining Sustainable Yield for Floridan Aquifer System. Hydrological Processes, 17, 1785-1809. https://doi.org/10.1002/hyp.1213

[44] Bacchus, S.T., Archibald, D.D., Britton, K.O. and Haines, B.L. (2005) Near Infrared Model Development for Pond-Cypress Subjected to Chronic Water Stress and Botryosphaeria rhodina. Acta Phytopathologica et Entomologica Hungarica, 40, 251-265. https://doi.org/10.1556/APhyt.40.2005.3-4.6

[45] Bernardes, S., He, J., Bacchus, S.T., Madden, M. and Jordan, T. (2014) Mitigation Banks and Other Conservation Lands at Risk from Preferential Groundwater Flow and Hydroperiod Alterations by Existing and Proposed Northeast Florida Mines. Journal of Sustainable Development, 7, 37. https://doi.org/10.5539/jsd.v7n4p225

[46] Cunningham, K.J., Renken, R., Wacker, M. and Zygnerski, M. (2006) Application of Carbonate Cycle Stratigraphy to Delineate Porosity and Preferential Flow and to Assess Advective Transport in the Karst Limestone of the Biscayne Aquifer. Proceedings of the Geological Society of America Annual Meeting and Exposition, Seattle, 191-208.

[47] Fitterman, D.V. and Deszcz-Pan, M. (1999) Geophysical Mapping of Saltwater In- 
trusion in Everglades National Park. US Geological Survey Open-File Report, US Geological Survey, Boca Raton, 99-181.

[48] Hofstetter, R.H. and Sonenshein, R.S. (1990) Vegetative Changes in a Wetland in the Vicinity of a Well Field, Dade County, Florida. US Geological Survey, Tallahassee.

[49] Maslia, M.L. and Prowell, D.C. (1990) Effect of Faults on Fluid-Flow and Chloride Contamination in a Carbonate Aquifer System. Journal of Hydrology, 115, 1-49. https://doi.org/10.1016/0022-1694(90)90196-5

[50] McNeill, D. (2000) A Review of Upward Migration of Effluent Related to Subsurface Injection at Miami-Dade Water and Sewer South District Plant. Prepared for the Sierra Club-Miami Group.

[51] Odum, J.K., et al. (1998) Land-Based High-Resolution Seismic Reflection Image of a Karst Sinkhole and Solution Pipe on Fort George Island, Duval County, Northeastern Florida. Symposium on the Application of Geophysics to Environmental and Engineering Problems at the Annual Meeting of the Environmental and Engineering Geophysical Society, Chicago, 22-26 March 1998, 285-294. https://doi.org/10.4133/1.2922514

[52] Patten, T.H. and Klein, J.-G. (1989) Sinkhole Formation and Its Effect on Peace River Hydrology. Proceedings of the 3 rd Multidisciplinary Conference on Sinkholes and the Engineering and Environmental Impacts of Karst, St. Petersburg Beach, 2-4 October 1989, 25-31.

[53] Price, R.E. and Pichler, T. (2004) Arsenic and Aquifer Storage and Recovery in Southwest Florida: Source, Abundance, and Mobilization Mechanism, Suwannee Limestone, Upper Floridan Aquifer. Aquifer Storage Recovery 4: Science, Technology, Management and Policy Conference, Tampa, 15-16 April 2004, 13.

[54] Renken, R.A., et al. (2004) Pathogen Transport in a Sole Source Karst Aquifer near a Public Well Field-Will Everglades Limestone Mine Expansion Pose a Clear and Present Danger to Public Health? Geoscience in a Changing World: Annual Meeting and Exposition, Denver, 7-10 November 2004, 396.

[55] Sonenshein, R.S. and Hofstetter, R.H. (1990) Hydrologic Effects of Well-Field Operations in a Wetland, Dade County, Florida. US Geological Survey Water-Resources Investigations Report 90-4143, US Geological Survey.

[56] Wilcox, W.M., Solo-Gabriele, H.M. and Sternberg, L.O.R. (2004) Use of Stable Isotopes to Quantify Flows between the Everglades and Urban Areas in Miami-Dade County Florida. Journal of Hydrology, 293, 1-19.

https://doi.org/10.1016/j.jhydrol.2003.12.041

[57] Xu, W., Bernardes, S., Bacchus, S.T. and Madden, M. (2016) Mapped Fractures and Sinkholes in the Coastal Plain of Florida and Georgia to Infer Environmental Impacts from Aquifer Storage and Recovery (ASR) and Supply Wells in the Regional Karst Floridan Aquifer System. Journal of Geography and Geology, 8, 76-110. https://doi.org/10.5539/jgg.v8n2p76

[58] Aurit, M.D., Peterson, R.O. and Blanford, J.I. (2013) A GIS Analysis of the Relationship between Sinkholes, Dry-Well Complaints and Groundwater Pumping for Frost-Freeze Protection of Winter Strawberry Production in Florida. PLoS ONE, 8, e53832. https://doi.org/10.1371/journal.pone.0053832

[59] Godfrey, R.K. (1988) Trees, Shrubs, and Woody Vines of Northern Florida and Adjacent Georgia and Alabama. University of Georgia Press, Athens.

[60] Bacchus, S.T. (1999) Cumberland Island National Seashore: Linking Offshore Im- 
pacts to Mainland Withdrawals from a Regional Karst Aquifer. Proceedings of the 1999 Georgia Water Resources Conference, Athens, 30-31 March 1999, 463-472.

[61] Litvaitis, J.A., Titus, K. and Anderson, E.M. (1996) Measuring Vertebrate Use of Terrestrial Habitats and Foods. In: Bookhout, T.A., Ed., Research and Management Techniques for Wildlife and Habitats, Allen Press, Lawrence, 254-274.

[62] Wise, W.R., Annable, M.D., Walser, J.A.E., Switt, R.S. and Shaw, D.T. (2000) A Wetland-Aquifer Interaction Test. Journal of Hydrology, 227, 257-272. https://doi.org/10.1016/S0022-1694(99)00188-2

[63] Florida Natural Areas Inventory and Florida Department of Natural Resources (1990) Guide to the Natural Communities of Florida. Florida Natural Areas Inventory and Florida Department of Natural Resources, Tallahassee. 